UDC 618.19-006.6-091.8:575.113

\title{
Heterogeneity of premetastatic niche gene expression in breast cancer cells
}

\author{
L. A. Tashireva ${ }^{1}$, E. V. Denisov ${ }^{2,3}$, O. E. Savelieva ${ }^{1,3}$, T. S. Gerashchenko ${ }^{2,3}$, \\ M. V. Zavyalova ${ }^{1,3,4}$, V. M. Perelmuter ${ }^{1,4}$ \\ ${ }^{1}$ Department of Pathological Anatomy and Cytology, Tomsk Cancer Research Institute, \\ 5, Kooperativny Street, Tomsk, Russian Federation, 634050 \\ ${ }^{2}$ Laboratory of Molecular Oncology and Immunology, Tomsk Cancer Research Institute, \\ 36, Lenina ave, Tomsk, Russian Federation, 634050 \\ ${ }^{3}$ Laboratory for Translational Cellular and Molecular Biomedicine, Tomsk State University, \\ 36, Lenina ave, Tomsk, Russian Federation, 634050 \\ ${ }^{4}$ Department of Pathological Anatomy, Siberian State Medical University, \\ 2, Moskovsky tr., Tomsk, Russian Federation, 634050 \\ tashireva@oncology.tomsk.ru
}

\begin{abstract}
Aim. To investigate the expression of the TGFB1, TNF, CSF1, CSF2, VEGFA and HIF1A genes in the patients with invasive breast carcinoma of no special type considering the intratumoral morphological heterogeneity. Methods. The technology of laser capture microdissection PALM was used to isolate five types of morphological tumor structures from three patients with invasive carcinoma of no special type (IC NST), luminal A subtype, T1-2NxMx. The level of expression of the cytokine (TNF), growth factors (TGFB1, CSF1, CSF2, $V E G F A$ ) and the HIF $1 A$ genes was assessed in the samples obtained using quantitative real-time PCR. Results. The study demonstrated the absence of the expression of the growth factor CSF2 gene in tumor cells of IC NST, and the expression of the CSF1 gene, independent from the metastasis status and tumor structure type. The prevalence of the expression of the VEGFA and TGFB1 genes was revealed in the alveolar and solid structures along with the rare expression of the $T N F$ gene. Conclusions. The expression of pre-metastatic niche genes in the tumors of patients with IC NST is heterogeneous. The hypoxia-mediated change in the cytokine gene expression may be expected in the alveolar and solid structures, which ultimately results in the formation of microenvironment, facilitating tumor growth and the formation of tumor metastatic potential.
\end{abstract}

Ke y w o r d s: breast cancer, pre-metastatic niche, morphological heterogeneity.

\section{Introduction}

According to the concept, suggested by Prof. D. Lyden (2005), the occurrence of metastases is preceded by the formation of so-called pre-metastatic niches - the optimal cellular and molecular microenvironment "foundation", far from the localization of the initial tumor [1]. The niche, so-called "tumor niche", is formed just in the initial tumor. Similar to the pre-metastatic niche, the biological essence of the tumor niche is to provide optimal conditions for the initial tumor growth. The key process of the tumor niche formation is recruitment of bone-marrow derived cells, their proliferation and differentiation in tumors [2]. This is possible due to the production of cytokines, chemokines and growth factors by tumor cells [3]. For instance, the secretion of vascular endothelial growth factor (VEGF) by tumor cells, which impacts endothelium progenitor cells, induces the stimulation of neoangiogenesis [4]. Such mole-

(C) 2015 L. A. Tashireva et al.; Published by the Institute of Molecular Biology and Genetics, NAS of Ukraine on behalf of Biopolymers and Cell. This is an Open Access article distributed under the terms of the Creative Commons Attribution License (http://creativecommons.org/licenses/by/4.0/), which permits unrestricted reuse, distribution, and reproduction in any medium, provided the original work is properly cited 
cules, as the macrophage colony-stimulating factor (M-CSF) and the granulocyte macrophage colonystimulating factor (GM-CSF), produced by the tumor cells, are the growth factors for haematopoietic stem cells, which give rise to leukocytes and macrophages, playing a leading role in the determination of tumor microenvironment properties $[5,6]$. The transforming growth factor- $\beta$ (TGF- $\beta$ ) is known for its capability to recruit mesenchymal stem cells [7]. It was demonstrated that mesenchymal stem cells, actively recruited to the places of tumor formation, are capable of differentiating into fibroblasts inside the tumor, thus forming up to $20 \%$ of its stroma [8]. Therefore, the tumor cells form and maintain their microenvironment [9].

One of the relevant characteristics of malignant tumors is their heterogeneity [10]. It was previously revealed by our group that in the case of invasive breast carcinoma of no special type (IC NST) the heterogeneity is related to the formation of different morphological tumor structures: alveolar, solid, trabecular, tubular and discrete groups of tumor cells [11-13]. This morphological heterogeneity likely is mediated by functional differences between tumor cells in different structures and related to the tumor progression $[12,14,15]$.

Due to this fact the aim of this study was to investigate the expression of TGFB1 (transforming growth factor- $\beta$ ), TNF (tumor necrosis factor- $\alpha$ ), growth factors CSF1 (M-CSF), CSF2 (GM-CSF) VEGFA (vascular endothelial growth factor), and HIF $1 A$ (hypoxia-induced factor-1) genes in patients with IC NST with the consideration of intratumor morphological heterogeneity.

\section{Materials and Methods}

Tumor samples of three patients with IC NST were used in the work: patient \#1 (49 y.o., luminal A, T1NxMx, grade 2), patient \#2 (61 y.o., luminal A, T2NxMx, grade 2), patient \#3 (61 y.o., luminal A, T2NxMx, grade 2), treated in the clinic of Tomsk Cancer Research Institute. The approval of the study was received from the local ethical committee of the Tomsk Cancer Research Institute (N 10, dated September 29, 2011).
The patients did not undergo any pre-surgical treatment. The histological type of cancer was established in accordance with WHO recommendations (Geneva, 2012) [16]. The analysis of histological sections of the tumor tissue, including the identification of different morphological structures, the character of stroma, hyalinosis and inflammatory infiltration in tumor microenvironment was performed using Carl Zeiss Axio Lab.A1 light microscope pursuant to the previously described method $[13,15]$.

The preparation of frozen-tissue sections of tumors was made using a cryostat (HM525, Thermo Scientific, USA), with subsequent staining the samples with haematoxylin and eosin (Dako, Denmark). The method of laser capture microdissection PALM (Carl Zeiss, Germany) was used to isolate from 150 to 200 samples of each type of morphological tumor structures (Fig. 1) as previously described [14]. The material, obtained for each morphological structure, was used to isolate total RNA using RNeasy Micro Kits (Qiagen, USA), and to amplify the transcriptome using QuantiTect WTA Kit (Qiagen, USA). The amount of RNA obtained was assessed by RIN score using 2200 TapeStation instrument and High Sensitivity R6K ScreenTape (Agilent Technologies, Inc., Santa Clara, USA).

The assessment of the expression level for the cytokine $(T N F)$, the growth factor (TGFB1, CSF1, $C S F 2, V E G F A$ ) and the $H I F 1 A$ genes in breast tumor samples was performed by real-time PCR, based on the technology of TaqMan-probes (FAM--BHQ-1) and specific oligonucleotides using the thermocycler Rotor-Gene-6000 (Corbett Research, Australia) (Table 2).

Table 2. Sequence of primers and probes

\begin{tabular}{|l|c|}
\hline \multicolumn{1}{c|}{ Gene } & Forward primer \\
\hline$C S F 1$ & 5'-GAGCCAGCATCCGTCCGT - 3' \\
$C S F 2$ & 5'-GGCGTCTCCTGAACCTGA - 3' \\
$V E G F A$ & 5'-CAGATTATGCGGATCAAACCT-3' \\
$T N F$ & 5'-CTGTAGCCCATGTTGTAGCAA-3' \\
$T G F B 1$ & 5'-CCACCCCGCTGGAGAGG-3' \\
$H I F 1 A$ & 5'-GGAACCTGATGCTTTAACTTTG - 3' \\
$A C T B$ & 5'-GAGAAGATGACCCAGATCATGTT-3' \\
\hline
\end{tabular}




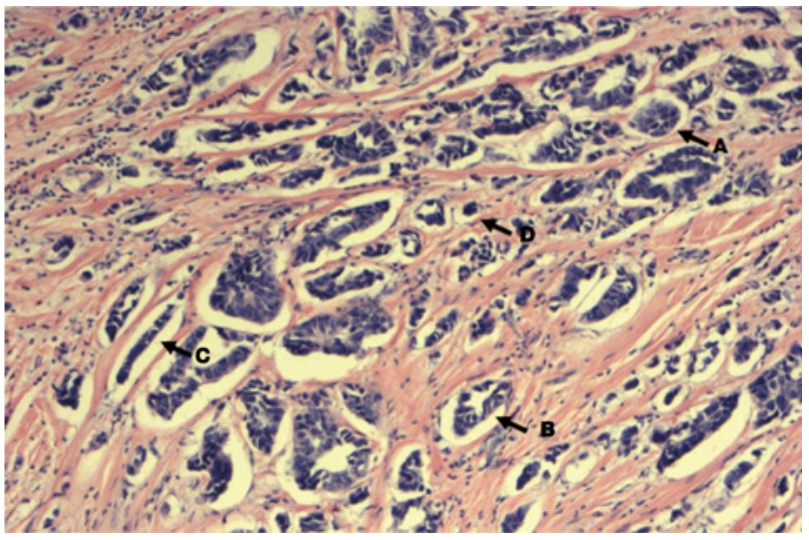

Fig. 1. Morphological heterogeneity of IC NST. $A-$ alveolar structure, $B$ - tubular structure, $C$ - trabecular structure, $D$-discrete group of tumor cells. The frozen-tissue sections of breast tumor tissues. Staining with haematoxylin and eosin. Magnification $\mathrm{x} 100$

The amplification of each sample was conducted three times. The relative expression level was estimated by Pfaffl's method [17]. The "housekeeping" gene - $A C T B$ - was used to normalize the expression level.

The data were statistically processed using SPSS 11.0 software (SPSS, Chicago, USA). The criterion $\chi 2$ was used to check the compliance with the selected hypothesis. The differences were deemed reliable at the relevance level of $\mathrm{p}<0.05$.

\section{Results and Discussion}

The formation of conditions for the cell proliferation and differentiation in the tumor is a vital factor of the tumor progression, i.e. relapses and metastasis. The synthesis of growth factors by the tumor cells is re-

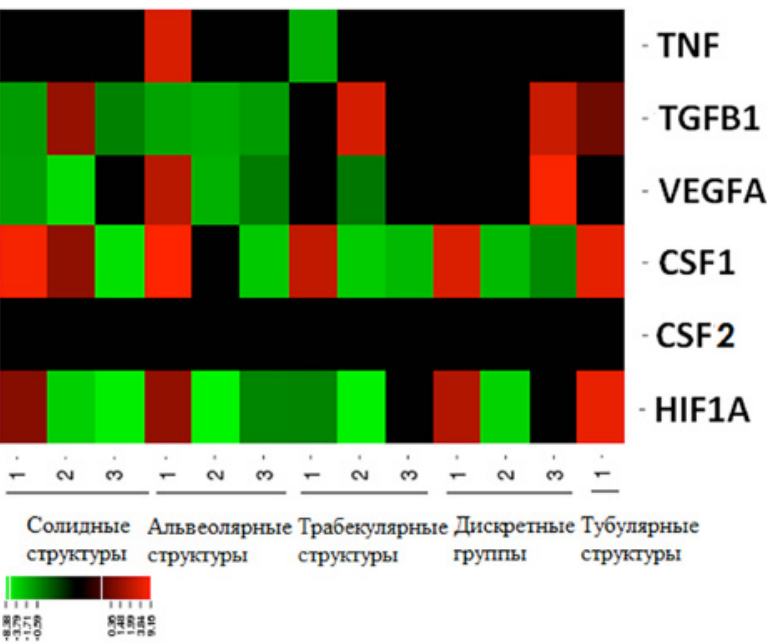

Fig. 2. The expression of pre-metastatic niche genes in the morphological structures of breast tumors. 1,2,3 - patients; TNF - tumor necrosis factor- $\alpha$; TGFB1 - transforming growth factor- $\beta$; $V E G F A$ - vascular endothelial growth factor- $\alpha$; CSF1 - macrophage colony-stimulating factor; $C S F 2$ - granulocyte macrophage colony-stimulating factor; $H I F 1 A$ - hypoxia-inducible factor

lated to these conditions. Notably, all three patients, involved in the study, differ in their status of the lymphatic cancer spread. The patient \#1 did not have any lymphatic involvement, the patient \#2 had one affected lymph node $(1 / \mathrm{n})$ out of 18 , and the patient \#3 had metastases in 8 out of 8 remote $1 / n$.

It was established in each patient, the expression profile of the studied genes, was heterogeneous in both the number of expressing genes, and the expression level for different structures (Fig. 2). Previously the tumor structures of IC NST were divided by us into two groups. The first group includes

\begin{tabular}{|c|c|}
\hline Reverse primer & Probe \\
\hline 5'-GGTCAGGAGAAGGTCAGGGC - 3' & 5'-CACTCTCCAGCCTCTCCCCAGC-3' \\
5'- TCTGTAGGCAGGTCGGCT-3' & 5'-ACTGCTGCTGAGATGAATGAAACA-3' \\
5'-GCTCTATCTTTCTTTGGTCTGC-3' & 5'-GCCAGCACATAGGAGAGATGAGC-3' \\
5'-TATCTCTCAGCTCCACGCC-3' & 5'-CTCCAGTGGCTGAACCGCCG-3' \\
5'-GCCGCACGCAGCAGTTC-3' & 5'-CACCAACTATTGCTTCAGCTCCACGG-3' \\
5'-AGTTTCTGTGTCGTTGCTGC-3' & 5'-AGCCGCTGGAGACACAATCAT-3' \\
5'-ATAGCACAGCCTGGATAGCAA-3' & 5'-AGACCTTCAACACCCCAGCCAT-3' \\
\hline
\end{tabular}


the tubular, trabecular structures and the discrete groups of tumor cells, and is remarkable that the tumor cells therein are connected both to each other and to stroma. It means that all tumor cells have both a set of molecules for cell-cell adhesion (cadherincatenin complex and integrins of $\beta 1$ family) and integrin receptors to adhere to stromal elements. The second group, comprising alveolar and solid structures, is notable for the fact that most tumor cells are connected to each other and are not adhered to stroma. The exception is found in the external layer of cells, contacting with the connective tissue. We have assumed that most tumor cells in such structures express the cadherin-catenin complex, but loses the integrin receptors, responsible for the connection to stroma [18].

A relevant factor, determining the recruitment of progenitor, is the presence of chronic inflammation $[19,20]$. Regardless of the initial cause, the formation of chronic inflammatory infiltration may be caused by pro-inflammatory cytokines, $T N F a$ being the most relevant of them. It was demonstrated by us that the $T N F$ gene was expressed only in the alveolar and trabecular tumor structures of the patient \#1 with no lymphatic metastasis. The inflammatory infiltration in the tumor stroma of the patient \#1 was moderately expressed, whereas it was weak or absent in the patients \#2 and \#3.

The expression of the TGFB1 gene was revealed in the alveolar and solid structures of all three patients (Fig. 2). While producing TGF $\beta$, the tumor promotes recruiting such cells as M2-macrophages into the sources of chronic inflammation [21]. Additionally, TGF $\beta$ is one of the triggers of epithelial-mesenchymal transition - the mechanism, underlying the invasive growth and metastasis of the tumor [22]. Notably, the TGFB1 gene is expressed mainly in the structures, related to the second group (alveolar and solid structures). In our opinion, it may be explained by hypoxia of the tumor cells in large cellular clusters. It was demonstrated that hypoxia may induce epithelial-mesenchymal transition [23], which is likely to take place via TGF- $\beta$ [24].
The angiogenic molecule of VEGF is capable of recruiting the endothelial progenitor cells and causing the homing of mesenchymal stem cells into the tumor [25]. In this context the probable relevance of hypoxia is proven by the expression of the VEGFA gene in alveolar structures in all 3 cases and in solid structures - in 2 out of 3 cases, whereas in trabecular structures and discrete groups of tumor cells the gene $V E G F A$ is expressed in 1 out of 3 cases.

The analysis of the expression of HIFIA gene demonstrated that the gene activation is observed in all the morphological structures, except for trabecular and discrete groups of tumor cells in the patient \#3, but the highest expression was notable for the patient \#1 in alveolar and solid structures (Fig. 2).

It is known that hypoxia induces the HIF-dependent expression of the CSF-1 (M-CSF) gene via direct binding to two sites of the 5'-flanking region [26]. The highest level of expression of the CSF1 gene was revealed in the alveolar and solid structures of the patient \#1. In the patients \#2 and \#3 mRNA of the CSF 1 gene was also found in all the morphological structures of the tumor, except for the alveolar structures of patient \#2 (Fig. 2). Additionally, M-CSF is a poietic hormone for the dendrite cells, which play a relevant role in the tumor progression [27].

The expression of the CSF 2 gene was not revealed in any studied sample (Fig. 2). There are data on the capability of M-CSF to promote the polarization of M2 macrophages, whereas] GM-CSF mediates the induction of M1 macrophages, associated with the anti-tumor response [28].

\section{Conclusions}

The results of the study prove the heterogeneous character of the expression of genes, responsible for the synthesis of chemoattractants, recruiting the progenitor cells of fibroblasts, endothelium and macrophages into the initial tumor. In most cases the TGFB 1 and VEGFA genes are expressed in the alveolar and solid structures, where most tumor cells do not have any direct connection with the stroma. Due to this fact, the central cells of these structures may have hypoxia at any degree of the 
stroma vascularization. On the one hand, hypoxia leads to the synthesis of HIF1A and VEGFA, mediating the recruitment of the bone marrow progenitor cells of endothelium and the stimulation of angiogenesis. On the other hand, hypoxia causes the adaptive changes in cells. One of the mechanisms of enhancing resistance to hypoxia is the epithelialmesenchymal transition. This may be a likely explanation of the synthesis of TGF $\beta$ in alveolar and solid structures, first of all. It may be assumed that the impact of TGF $\beta$ induces the recruitment of the mesenchymal stem progenitor cells of fibroblasts and M2-macrophages into the stroma, which, along with the abovementioned events, supports the microenvironment, promoting the tumor growth, i.e. the formation of the tumor niche. The results obtained suggest that when the pathologist reveals the alveolar and solid structures in the tumor, he may expect the hypoxia-mediated change in the cytokine gene expression, which ultimately results in the formation of microenvironment, facilitating tumor growth and the formation of tumor metastatic potential. The absence of the expression of the gene of growth factor GM-CSF and rare expression of the $T N F$ gene in tumor cells are in agreement with the infrequent occurrence of segmental leukocytes in the stroma of breast cancer.

Currently, this work is a pilot study, the results of which reflect a high degree of the heterogeneity of gene expression not only between the groups with different structures but also inside these groups. This fact causes some difficulties in the interpretation of the results obtained, but it highlights the urgency and relevance of the problem study.

\section{Funding}

The study was conducted with the financial support of the grant of the Russian Foundation for Basic Research (Project \#15-34-20864, assessment of gene expression) and the Russian Scientific Foundation (project \#14-15-00318, the set of material under investigation, laser capture microdissection).

E. V. Denisov was supported by Tomsk State University Competitiveness Improvement Program.
L. A. Tashireva was supported by the Russian Federation President's Scholarship

\section{REFERENCES:}

1. Kaplan RN, Riba RD, Zacharoulis S, Bramley AH, Vincent L, Costa C, MacDonald DD, Jin DK, Shido K, Kerns SA, Zhu Z, Hicklin D, Wu Y, Port JL, Altorki N, Port ER, Ruggero D, Shmelkov SV, Jensen KK, Rafii S, Lyden D. VEGFR1-positive haematopoietic bone marrow progenitors initiate the pre-metastatic niche. Nature. 2005; 438(7069):820-7.

2. Barcellos-Hoff MH, Lyden D, Wang TC. The evolution of the cancer niche during multistage carcinogenesis. Nat Rev Cancer. 2013;13(7):511-8.

3. Catalano V, Turdo A, Di Franco S, Dieli F, Todaro M, Stassi $G$. Tumor and its microenvironment: a synergistic interplay. Semin Cancer Biol. 2013;23(6 Pt B):522-32.

4. Marçola $M$, Rodrigues $C E$. Endothelial progenitor cells in tumor angiogenesis: another brick in the wall. Stem Cells Int. 2015;2015:832649.

5. Danova $M$, Aglietta $M$. Cytokine receptors, growth factors and cell cycle in human bone marrow and peripheral blood hematopoietic progenitors. Haematologica. 1997; 82(5):622-9.

6. Boulais PE, Frenette PS. Making sense of hematopoietic stem cell niches. Blood. 2015;125(17):2621-9.

7. Crane JL, Cao X. Bone marrow mesenchymal stem cells and TGF- $\beta$ signaling in bone remodeling. $J$ Clin Invest. 2014;124(2):466-72.

8. Kidd S, Spaeth E, Watson K, Burks J, Lu H, Klopp A, Andreeff $M$, Marini FC. Origins of the tumor microenvironment: quantitative assessment of adipose-derived and bone marrow-derived stroma. PLoS One. 2012;7(2):e30563.

9. Hass R, Otte A. Mesenchymal stem cells as all-round supporters in a normal and neoplastic microenvironment. Cell Commun Signal. 2012;10(1):26.

10. Gerashchenko TS, Denisov EV, Litviakov NV, Zavyalova MV, Vtorushin SV, Tsyganov MM, Perelmuter VM, Cherdyntseva $N V$. Intratumor heterogeneity: nature and biological significance. Biochemistry (Mosc). 2013;78(11): 1201-15.

11. Zavjalova MV, Perelmuter VM, Slonimskaya EM, Vtorushin SV, Garbukov EYu, Gluschenko SA. Conjugation of lymphogenous metastatic spread and histologic pattern of infiltrative component of ductal breast cancer. Siberian Journal of Oncology. 2006; 1: 32-5.

12. Zavyalova MV, Perelmuter VM, Vtorushin SV, Denisov EV, Litvyakov NV, Slonimskaya EM, Cherdyntseva NV. The presence of alveolar structures in invasive ductal NOS breast carcinoma is associated with lymph node metastasis. Diagn Cytopathol. 2013;41(3):279-82. 
13. Zavyalova MV, Denisov EV, Tashireva LA, Gerashchenko $T S$, Litviakov NV, Skryabin NA, Vtorushin SV, Telegina NS, Slonimskaya EM, Cherdyntseva NV, Perelmuter VM. Phenotypic drift as a cause for intratumoral morphological heterogeneity of invasive ductal breast carcinoma not otherwise specified. Biores Open Access. 2013;2(2):148-54.

14. Denisov EV, Litviakov NV, Zavyalova MV, Perelmuter VM, Vtorushin SV, Tsyganov MM, Gerashchenko TS, Garbukov EY, Slonimskaya EM, Cherdyntseva NV. Intratumoral morphological heterogeneity of breast cancer: neoadjuvant chemotherapy efficiency and multidrug resistance gene expression. Sci Rep. 2014;4:4709.

15. Denisov EV, Gerashchenko TS, Zavyalova MV, Litviakov NV, Tsyganov MM, Kaigorodova EV, Slonimskaya EM, Kzhyshkowska J, Cherdyntseva NV, Perelmuter VM. Invasive and drug resistant expression profile of different morphological structures of breast tumors. Neoplasma. 2015;62(3):405-11.

16. Lakhani SR, Ellis IO, Schnitt SJ, Tan PH, van de Vijver MJ. World Health Organization (WHO) classification of tumours of the breast. 4th Ed. Lyon: IARC Press, 2012. 240 p.

17. Pfaff $M W$. A new mathematical model for relative quantification in real-time RT-PCR. Nucleic Acids Res. 2001;29(9):e45.

18. Perelmuter VM, Zavyalova MV, Vtorushin SV, Slonimskaya $E M$, Savenkova $O V$. Interaction between morphologic heterogeneity of infiltrating ductal breast carcinoma and various forms of tumor progression. Siberian Journal of Oncology. 2007; 3: 58-63.

19. Perelmuter VM, Manskikh VN. Preniche as missing link of the metastatic niche concept explaining organ-preferential metastasis of malignant tumors and the type of metastatic disease. Biochemistry (Mosc). 2012;77(1):111-8.

20. Perelmuter VM, Manskikh VN. The Concept of a preniche for localization of future metastases. tumors of the central nervous system types of tumors, diagnosis, ultrasonography, surgery, brain metastasis, and general CNS diseases. Springer, 2014. 308 p.

21. Turner MD, Nedjai B, Hurst T, Pennington DJ. Cytokines and chemokines: At the crossroads of cell signalling and inflammatory disease. Biochim Biophys Acta. 2014;1843(11):2563-82.

22. Gonzalez DM, Medici D. Signaling mechanisms of the epithelial-mesenchymal transition. Sci Signal. 2014;7(344):re8.

23. Marie-Egyptienne DT, Lohse I, Hill RP. Cancer stem cells, the epithelial to mesenchymal transition (EMT) and radioresistance: potential role of hypoxia. Cancer Lett. 2013;341(1):63-72.

24. Feng Z, Li R, Shi H, Bi W, Hou W, Zhang X. Combined silencing of TGF- $\beta 2$ and Snail genes inhibit epithelial-mesenchymal transition of retinal pigment epithelial cells under hypoxia. Graefes Arch Clin Exp Ophthalmol. 2015;253(6):875-84.

25. Lee SH, Jeong D, Han YS, Baek MJ. Pivotal role of vascular endothelial growth factor pathway in tumor angiogenesis. Ann Surg Treat Res. 2015;89(1):1-8.
26. Chaturvedi P, Gilkes DM, Takano N, Semenza GL. Hypoxia-inducible factor-dependent signaling between triple-negative breast cancer cells and mesenchymal stem cells promotes macrophage recruitment. Proc Natl Acad Sci US A. 2014;111(20):E2120-9.

27. Fancke B, Suter M, Hochrein H, O'Keeffe M. M-CSF: a novel plasmacytoid and conventional dendritic cell poietin. Blood. 2008;111(1):150-9.

28. Quatromoni JG, Eruslanov E. Tumor-associated macrophages: function, phenotype, and link to prognosis in human lung cancer. Am J Transl Res. 2012;4(4):376-89.

\section{Гетерогенність експресії генів преметастатичних ніш} пухлинними клітинами раку молочної залози

Л. А. Ташірева, С. В. Денісов, О. Е. Савельєва, Т. С. Геращенко, М. В. Зав'ялова, В. М. Перельмутер

Мета. Вивчення експресії генів TGFB1, TNF, CSF1, CSF2, $V E G F A$ і $H I F 1 A$ у хворих з інвазивною карциномою молочної залози неспецифічного типу з урахуванням внутрішньопухлинної морфологічної гетерогенності. Методи. Із застосуванням технології лазерної мікродисекції PALM проводилося виділення п'яти типів морфологічних структур пухлини від 3 хворих інвазивною карциномою молочної залози неспецифічного типу (IC NST), люмінальний А підтип, T1-2NxMx. В отриманих зразках методом ПЛР в режимі «реального часу» 3 використанням TaqMan-зондів і специфічних олігонуклеотидів була проведена оцінка рівня експресії генів цитокінів (TGFB1 $i T N F)$, генів факторів росту (CSF1, CSF2, VEGFA) i гена $H I F 1 A$. Результати. Проведене дослідження показало відсутність експресії гена ростового фактора CSF2 в пухлинних клітинах IC NST, а також незалежну від статусу метастазування і типу структури експресію гена $C S F 1$. Було виявлено переважання експресії генів VEGFA і TGFB1 в альвеолярних і солідних структурах, а також рідкісна експресія гена TNF. Висновки. Експресія генів преметастатичних ніш в пухлинах хворих 3 IC NST гетерогенна. В альвеолярних і солідних структурах можна очікувати опосередковану гіпоксією зміну експресії генів хемоаттрактантів, що, в кінцевому рахунку, веде до формування мікрооточення, що сприяє зростанню пухлини і формуванню метастатичного потенціалу пухлини.

Кл юч ов і сл ов а: рак молочної залози, преметастатична ніша, морфологічна гетерогенність.

\section{Гетерогенность экспрессии генов преметастатических ниш опухолевыми клетками рака молочной железы}

Л. А. Таширева, Е. В. Денисов, О. Е. Савельева, Т. С. Геращенко, М. В. Завьялова, В. М. Перельмутер

Цель. Изучение экспрессии генов TGFB1, TNF, CSF1, CSF2, $V E G F A$ и $H I F 1 A$ у больных инвазивной карциномой молочной 
железы неспецифического типа с учетом внутриопухолевой морфологической гетерогенности. Методы. С применением технологии лазерной микродиссекции PALM проводилось выделение пяти типов морфологических структур опухоли от 3 больных инвазивной карциномой молочной железы неспецифического типа (IC NST), люминальный А подтип, T1-2NxMx. В полученных образцах методом ПЦР в режиме «реального времени» с использованием TaqMan-зондов и специфических олигонуклеотидов была проведена оценка уровня экспрессии генов цитокинов (TNF), генов факторов роста (TGFB1, CSF1, $C S F 2, V E G F A)$ и гена HIF $1 A$. Результаты. Проведенное исследование показало отсутствие экспрессии гена ростового фактора CSF2 в опухолевых клетках IC NST, а также независимую от статуса метастазирования и типа структуры экспрессию гена $C S F 1$. Было выявлено преобладание экспрессии генов $V E G F A$ и $T G F B 1$ в альвеолярных и солидных структурах, а также редкая экспрессия гена TNF. Выводы. Экспрессия генов преметастатических ниш в опухоли у больных IC NST гетерогенна. В альвеолярных и солидных структурах можно ожидать опосредованное гипоксией изменение экспрессии генов цитокинов, в конечном счете, ведущее к формированию микроокружения, способствующего росту опухоли и формированию метастатического потенциала опухоли.

Кл юч е в ы е сл о а : рак молочной железы, преметастатическая ниша, морфологическая гетерогенность.

Received 24.06.2015 